\title{
Effect of lead on carbohydrate mobilization in oat seeds during germination
}

\section{${ }^{1}$ BHUSHAN, B; ${ }^{2 *}$ GUPTA, K}

\author{
${ }^{1}$ Department of Biochemistry, CCS Haryana Agricultural University, Hisar-125004 (India) bharat_srf@rediffmail.com \\ ${ }^{2 *}$ Professor, Forage Section, Department of Plant Breeding, CCS HAU, Hisar.
}

\begin{abstract}
In response to various concentrations of lead, the total amylolytic activity in the endosperm or embryonic axis of oat was suppressed 33 percent and 11 percent respectively while increased as germination advances towards 12 days at all treatment levels. Suppression of enzyme activity suggested that lead tended to retard the initial rise of enzyme activity. The results on starch utilization show reduced hydrolysis of major carbohydrate reserves in endosperm. Same trend was observed in the developing embryonic axis. It is suggested that seed metabolism is adversely affected by lead. @ JASEM
\end{abstract}

Heavy metal pollution has serious consequences for plant because of their toxicity, long persistence, bio accumulation and biomagnficaton in food chain (Whitton, 1970; Meagher, 2000; Raskin and Ensley, 2000). $\mathrm{Cd}^{+2}, \mathrm{Ni}^{2+}$ and $\mathrm{Pb}^{2+}$ toxicity to plant growth has been well documented in maize (Osuji et al., 1998), pea (Bansal, 2001), rye grass (Allinson and Dziala, 1981), Eichhornia (Odjegba and Fasidi, 2006) and in tomato (Khan and Khan, 1983; Jaja, E.T. and Odvemena CSI, 2004). Heavy metals including $\mathrm{Pb}$ (lead) have a profound deleterious effect on metabolism including reserve mobilization of germinating seeds. One of the crucial events during seed germination entails mobilization of seed reserves because it supplies substrate for functioning of different metabolic processes which are vital for growth of embryonic axis (Bewley, 1997). Many workers (Bansal, 2001; Deep et al., 2002; Mishra and Choudhuri, 1997) reported the toxic effects of lead on various aspects of seed germination. Therefore, it was of curiosity to examine the influence of lead on mobilization of starch, which happens to be a major reserve substrate during germination.

\section{MATERIALS AND METHODS}

The experiment were conducted on oat (Avena sativa L.) CV HJ-8 seeds procured from Forage Section, Department of Plant Breeding, CCS Haryana Agricultural University, Hisar, India. Seeds of uniform size and colour were selected and surface sterilized with 0.2 percent $(\mathrm{w} / \mathrm{v})$ mercuric chloride solution for one minute, washed thoroughly several times with glass distilled water and kept for germination in petriplates $(15 \mathrm{~cm}$ diameter) lines with two layers of whatmann No. 1 filter paper, $\mathrm{C}$ in a B.O.D. incubator maintained at $25^{\circ} \mathrm{C} \pm 1^{\circ} \mathrm{C}$. Seedling were irrigated with distilled water (control) or aqueous solutions of various concentrations $(25,50,100,200,300$ or $400 \mathrm{ppm})$ of lead. Seedlings were withdrawn at three days interval thoroughly washed with distilled water, endosperm and embryonic axis were separated, dried in an oven at $70^{\circ} \mathrm{C}$ until a constant weight was observed, ground to a fine powder and stored in a desicator over anhydrous calcium chloride. Soluble sugars were extracted (Marbach and Mayer, 1976) and estimated by Anthrone reagent method (Hedge and Hofreiter, 1962). Reducing sugars were estimated by Nelson's method (Nelson, 1994). Total, $\alpha$ and $\beta$ amylase activity were assayed (Swain-Dekker, 1966) and liberated maltose was estimated (Yomo-Varner, 1973) in the dialyzed extract.

\section{RESULT AND DISCUSSION}

A 21 percent retardation in starch utilization was recorded in endosperm of seeds germinated in 25 ppm lead solution while 33, 48, 67, 75 and 94 per cent retardation was observed in 50, 100, 200, 300 and $400 \mathrm{ppm}$ lead treatment after 3 days of germination as compare to that of control (Table 1). This retardation was found to be concentration dependent. Approximately $3.64 \mathrm{mg}$ of starch was utilized in endosperm sown in distilled water. Similar decrease in utilization of starch was also observed on other days after germination. Amount of starch increased with passage of time in embryonic axis upto 12 days after germination in all the treatments. The amount of starch in embryonic axis of control seeds between 3 and 12 days was $3.28 \mathrm{mg}$. After 12 days of germination, starch accumulation was considerably inhibited (39 percent) in embryonic axis when germinated in solution containing $400 \mathrm{ppm}$ lead. After 3 days of germination, amount of starch in the embryonic axis of seeds germinated in $25 \mathrm{ppm}$ lead was decreased by 29 percent as compared to the control. Similarly 30, 33, 41, 49 and 59 percent depression in starch accumulation in embryonic axis was registered in response to 50,100, 200, 300 and 400 ppm of lead respectively. Curtailed degradation of starch in response to heavy metal stress was proposed by Mishra and Choudhuri (1997). They recorded a greater dry mass of endosperm tissues of rice seeds germinated in solution of either lead or mercury and suggested that starch in the endosperm is not much solubilized by amylase and could not be consumed by the embryo. 
Table 1: Effect of lead on starch content in endosperm and embryonic axis of germinating oat seeds

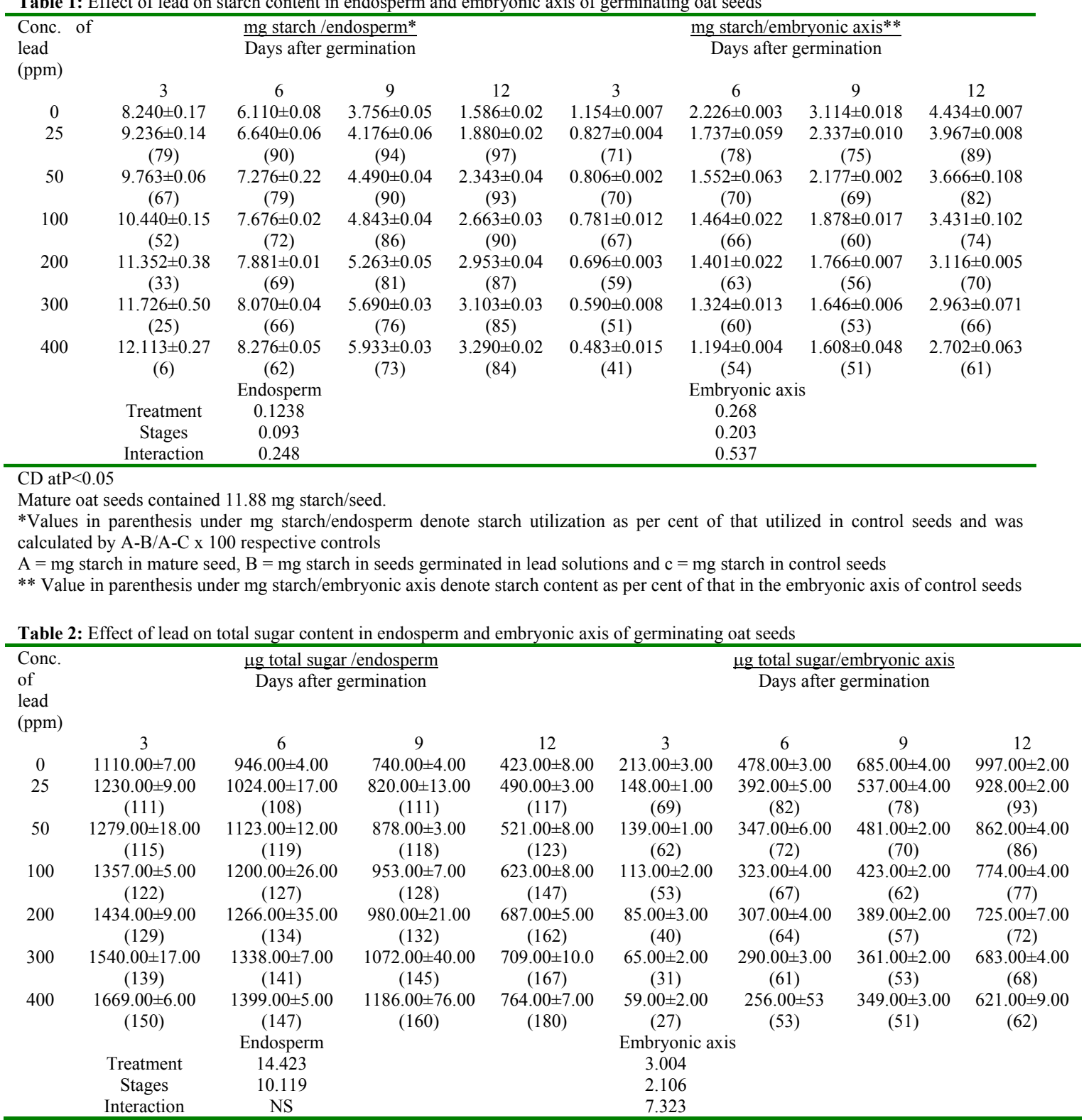

$\mathrm{CD}$ atP $<0.05$

Mature oat seeds contained $715 \mu \mathrm{g}$ total sugar per endosperm

Values in parenthesis denote total sugar content in endosperm and embryonic axis as per cent of that in respective controls

Mature oat seeds contained $715 \mu \mathrm{g}$ total sugar per seed. After 3 days of germination, control seeds contained $1110 \mu \mathrm{g}$ sugar i.e. approximately 1.5 times of that found in mature oat seeds and the total sugar content in endosperm of seeds in lead solutions was even higher (Table 2). Between 7-12 days of germination, starch degradation proceeded at a relatively faster rate as compared to initial stages. Thus the total sugar content declined in control seeds both due to slower mobilization of starch as well as further utilization of sugars in endosperm and also for growth of axis. On the $9^{\text {th }}$ day of germination the total sugar content in endosperm was $80,138,213,240,332$ and $446 \mu \mathrm{g}$ more when grown in given specified concentrations of lead than the sugar content in mature oat seeds.

\footnotetext{
* Corresponding author: Gupta, $\mathrm{K}$
}

Thus may be due to sustained deleterious effect of lead on utilization or due to interference of lead with transport of sugar from endosperm to growing axis. Results indicate that throughout the 12 days of germination, the sugar content in endosperm of seeds germinated in lead remained higher than the sugar content in control seed. During early stages of germination between 0-6 days, the higher amount of total sugar in endosperm may be due to accelerated depletion of starch and impaired utilization of sugar as well. Embryonic axis of control seeds contained about $213 \mu \mathrm{g}$ sugar after 3 days of germination, which increased further to 997 $\mu \mathrm{g}$ after 12 days of germination. After 3 days of germination, embryonic axis contained $31,38,47$, 60, 69 and 73 percent lesser total sugar content as 
compared to the control in response to specified concentration of lead respectively. Similar trend was observed on the $12^{\text {th }}$ day. Mishra and Choudhury (1997) reported impaired utilization of starch in rice endosperm and interference by lead in the translocation of sugar from endosperm to embryonic axis.

Amount of reducing sugar in endosperms of control seeds as well as in the lead treated seeds decreased with passage of time because of mobilization and utilization of these sugars for growth of embryonic axis (Table 3). Level of reducing sugars in the endosperms of seeds germinated in 25, 50, 100, 200, 300 and 400 ppm lead was about 7, 13, 19, 27, 30 and 33 per cent higher than that in the control endosperms after 3 days of germination and this effect was further accentuated to $19,32,51,64,79$ and 91 percent respectively after 12 days of germination. Depression of 27, 39, 51, 60, 65 and 71 percent in the reducing sugar content in the axis of germinated seeds in the lead was observed after 3 days of germination. This type of profile in reducing sugars may be ascribed to disruption in the supply of sucrose from endosperm either due to depressed synthesis or export. Similar increase in reducing sugar content in cotyledons of germinating pea seeds has been observed by Dua and Sawhney (1991) and Bansal (2001). Total amlyolytic activity was enhanced during 12 days of germination in endosperm of control as well as in the seeds germinated in presence of lead (Table 4). The enhancement in the amylolytic activities in the endosperm of control seeds was gradual between 6 and 9 days after germination followed by a faster rate of increase. After 3 days, approximately 12,
19, 22, 24, 26 and 29 percent inhibition in total amylolytic activity was observed in endosperm of seeds placed in 25, 50,100, 200, 300 and 400 ppm lead solution respectively. The decrease in the $\alpha$ amylase activity of endosperm was $6,11,14,19$, 22 and 27 percent in response to given specified concentration of lead after 6 days of germination, whereas the decrease in the activity was $15,20,26$, 30,42 and 44 percent after 12 days with increasing concentration of lead (Table 5). In the embryonic axis, total amylolytic activity was enhanced during 12 days of germination both in the axis of control as well as in the lead treated seeds. With increasing concentration, the inhibition of activity progressively increased and extent of inhibition got obviated with time. As it is clear from the activity observed after 3 days of germination was 93, 87, $63,55,48$ and 44 in response to specified concentration of lead (i.e. 25, 50, 100, 200, 300 and $400 \mathrm{ppm}$ ) compared to the activity observed in control. Other authors also reported the similar trend in amylolytic activity during germination as affected by various heavy metals in variety of seeds including wheat (Thimmaiah, 1989), rice (Mukherji and Mukherji, 1990), pea (Deep, 2002; Bansal, 2001; Dua and Sawhney, 1991). The increase in activities with the passage of time may be due to de novo synthesis and mild inhibition on $12^{\text {th }}$ day due to acclimatization of activities in response to lead. Bindu and Bera (2002) and Roy and Bera (2002) reported that reduction in the mobilization of cotyledonary reserves in mungbean might be due to inactivation of amylases by cadmium, mercury and manganese respectively.

Table 3: Effect of lead on reducing sugar content in endosperm and embryonic axis of germinating oat seeds

\begin{tabular}{|c|c|c|c|c|c|c|c|c|}
\hline \multirow{2}{*}{$\begin{array}{l}\text { Conc. } \\
\text { of lead } \\
(\mathrm{ppm})\end{array}$} & \multicolumn{4}{|c|}{$\frac{\mu g \text { reducing sugar/endosperm }}{\text { Days after germination }}$} & \multicolumn{4}{|c|}{$\frac{\mu \mathrm{g} \text { reducing sugar/embryonic axis }}{\text { Days after germination }}$} \\
\hline & 3 & 6 & 9 & 12 & 3 & 6 & 9 & 12 \\
\hline 0 & $636.00 \pm 4.00$ & $514.00 \pm 4.00$ & $390.00 \pm 2.00$ & $177.00 \pm 5.00$ & $89.00 \pm 1.00$ & $196.00 \pm 3.00$ & $264.00 \pm 3.00$ & $361.00 \pm 2.00$ \\
\hline 25 & $\begin{array}{c}681.00 \pm 5.00 \\
(107)\end{array}$ & $\begin{array}{c}559.00 \pm 2.00 \\
(108)\end{array}$ & $\begin{array}{c}419.00 \pm 3.00 \\
(107)\end{array}$ & $\begin{array}{l}242.00 \pm 4.00 \\
(119)\end{array}$ & $\begin{array}{c}65.00 \pm 2.00 \\
(73)\end{array}$ & $\begin{array}{c}164.00 \pm 3.00 \\
(83)\end{array}$ & $\begin{array}{c}212.00 \pm 6.00 \\
(80)\end{array}$ & $\begin{array}{c}326.00 \pm 4.00 \\
(90)\end{array}$ \\
\hline 50 & $\begin{array}{l}719.00 \pm 4.00 \\
(113)\end{array}$ & $\begin{array}{l}578.00 \pm 2.00 \\
(112)\end{array}$ & $\begin{array}{l}465.00 \pm 1.00 \\
\quad(119)\end{array}$ & $\begin{array}{l}235.00 \pm 8.00 \\
(132)\end{array}$ & $\begin{array}{l}54.00 \pm 3.00 \\
(61)\end{array}$ & $\begin{array}{l}151.00 \pm 2.00 \\
(77)\end{array}$ & $\begin{array}{l}196.00 \pm 4.00 \\
(74)\end{array}$ & $\begin{array}{l}288.00 \pm 2.00 \\
(80)\end{array}$ \\
\hline 100 & $\begin{array}{l}760.00 \pm 3.00 \\
(119)\end{array}$ & $\begin{array}{l}593.00 \pm 3.00 \\
\quad(115)\end{array}$ & $\begin{array}{l}490.00 \pm 2.00 \\
\quad(125)\end{array}$ & $\begin{array}{l}268.00 \pm 3.00 \\
\quad(151)\end{array}$ & $\begin{array}{c}44.00 \pm 5.00 \\
(49)\end{array}$ & $\begin{array}{l}138.00 \pm 2.00 \\
(70)\end{array}$ & $\begin{array}{c}171.00 \pm 2.00 \\
(64)\end{array}$ & $\begin{array}{l}274.00 \pm 3.00 \\
(76)\end{array}$ \\
\hline 200 & $\begin{array}{l}814.00 \pm 7.00 \\
\quad(127)\end{array}$ & $\begin{array}{l}624.00 \pm 7.00 \\
\quad(121)\end{array}$ & $\begin{array}{l}520.00 \pm 3.00 \\
\quad(133)\end{array}$ & $\begin{array}{l}291.00 \pm 2.00 \\
\quad(164)\end{array}$ & $\begin{array}{l}36.00 \pm 2.00 \\
\quad(40)\end{array}$ & $\begin{array}{l}132.00 \pm 1.00 \\
(67)\end{array}$ & $\begin{array}{l}155.00 \pm 4.00 \\
(58)\end{array}$ & $\begin{array}{l}266.00 \pm 3.00 \\
\quad(74)\end{array}$ \\
\hline 300 & $\begin{array}{c}830.00 \pm 16.0 \\
0(130)\end{array}$ & $\begin{array}{c}644.00 \pm 6.00 \\
(125)\end{array}$ & $\begin{array}{c}542.00 \pm 3.00 \\
(138)\end{array}$ & $\begin{array}{c}318.00 \pm 2.00 \\
(179)\end{array}$ & $\begin{array}{c}31.00 \pm 1.00 \\
(35)\end{array}$ & $\begin{array}{c}119.00 \pm 1.00 \\
(60)\end{array}$ & $\begin{array}{c}141.00 \pm 2.00 \\
(53)\end{array}$ & $\begin{array}{c}251.00 \pm 1.00 \\
(70)\end{array}$ \\
\hline 400 & $\begin{array}{l}847.00 \pm 5.00 \\
(133) \\
\\
\text { Treatment } \\
\text { Stages } \\
\text { Interaction }\end{array}$ & $\begin{array}{c}681.00 \pm 7.00 \\
(132) \\
\text { Endosperm } \\
4.000 \\
3.000 \\
10.000\end{array}$ & $\begin{array}{l}555.00 \pm 6.00 \\
\quad(142)\end{array}$ & $\begin{array}{l}339.00 \pm 3.00 \\
\quad(191)\end{array}$ & $\begin{array}{c}26.00 \pm 1.00 \\
(29) \\
\text { Embryonic axis } \\
2.900 \\
2.200 \\
6.000\end{array}$ & $\begin{array}{l}107.00 \pm 5.00 \\
\quad(54)\end{array}$ & $\begin{array}{l}133.00 \pm 7.00 \\
(50)\end{array}$ & $\begin{array}{l}246.00 \pm 2.00 \\
\quad(68)\end{array}$ \\
\hline
\end{tabular}

* Corresponding author: Gupta, $\mathrm{K}$ 
Table 4: Effect of lead on total amylase activity in endosperm and embryonic axis of germinating oat seeds

\begin{tabular}{|c|c|c|c|c|c|c|c|c|}
\hline \multirow{2}{*}{$\begin{array}{c}\text { Conc. } \\
\text { of } \\
\text { lead } \\
(\mathrm{ppm})\end{array}$} & \multicolumn{4}{|c|}{$\frac{\text { mg maltose produced/endosperm } / \mathrm{hr}}{\text { Days after germination }}$} & \multicolumn{4}{|c|}{$\frac{\text { mg maltose produced/embryonic axis } / \mathrm{hr}}{\text { Days after germination }}$} \\
\hline & 3 & 6 & 9 & 12 & 3 & 6 & 9 & 12 \\
\hline 0 & $27.90 \pm 0.18$ & $52.08 \pm 0.15$ & $58.95 \pm 0.21$ & $113.79 \pm 0.51$ & $12.15 \pm 0.18$ & $21.54 \pm 0.24$ & $38.58 \pm 0.21$ & $80.31 \pm 0.16$ \\
\hline 25 & $\begin{array}{l}24.57 \pm 0.16 \\
(88)\end{array}$ & $\begin{array}{l}51.17 \pm 0.15 \\
\quad(98)\end{array}$ & $\begin{array}{l}58.92 \pm 0.12 \\
\quad(100)\end{array}$ & $\begin{array}{l}110.73 \pm 1.38 \\
\quad(97)\end{array}$ & $\begin{array}{l}11.37 \pm 0.42 \\
(93)\end{array}$ & $\begin{array}{l}20.67 \pm 0.48 \\
\quad(96)\end{array}$ & $\begin{array}{l}36.39 \pm 0.22 \\
\quad(94)\end{array}$ & $\begin{array}{l}79.23 \pm 0.27 \\
(99)\end{array}$ \\
\hline 50 & $\begin{array}{l}22.86 \pm 0.16 \\
(81)\end{array}$ & $\begin{array}{l}46.47 \pm 0.18 \\
\quad(89)\end{array}$ & $\begin{array}{l}52.56 \pm 0.24 \\
(89)\end{array}$ & $\begin{array}{l}102.42 \pm 1.32 \\
(90)\end{array}$ & $\begin{array}{l}10.56 \pm 0.27 \\
(87)\end{array}$ & $\begin{array}{l}20.10 \pm 0.18 \\
\quad(93)\end{array}$ & $\begin{array}{l}35.67 \pm 0.20 \\
\quad(92)\end{array}$ & $\begin{array}{l}78.30 \pm 0.27 \\
(97)\end{array}$ \\
\hline 100 & $\begin{array}{c}21.66 \pm 0.16 \\
(78)\end{array}$ & $\begin{array}{c}44.64 \pm 0.16 \\
(86)\end{array}$ & $\begin{array}{c}50.66 \pm 0.18 \\
(86)\end{array}$ & $\begin{array}{c}96.93 \pm 1.65 \\
(85)\end{array}$ & $\begin{array}{c}7.62 \pm 0.12 \\
(63)\end{array}$ & $\begin{array}{c}18.69 \pm 0.26 \\
(87)\end{array}$ & $\begin{array}{c}34.47 \pm 0.10 \\
(89)\end{array}$ & $\begin{array}{c}77.31 \pm 0.16 \\
(96)\end{array}$ \\
\hline 200 & $\begin{array}{l}21.31 \pm 0.12 \\
(76)\end{array}$ & $\begin{array}{l}42.75 \pm 0.15 \\
\quad(82)\end{array}$ & $\begin{array}{l}48.74 \pm 0.15 \\
\quad(83)\end{array}$ & $\begin{array}{l}91.32 \pm 0.39 \\
(80)\end{array}$ & $\begin{array}{l}6.73 \pm 0.57 \\
(55)\end{array}$ & $\begin{array}{l}17.64 \pm 0.15 \\
(82)\end{array}$ & $\begin{array}{l}33.78 \pm 0.19 \\
\quad(87)\end{array}$ & $\begin{array}{c}76.11 \pm 0.39 \\
(95)\end{array}$ \\
\hline 300 & $\begin{array}{l}20.70 \pm 0.12 \\
\quad(74)\end{array}$ & $\begin{array}{l}41.06 \pm 0.15 \\
\quad(79)\end{array}$ & $\begin{array}{l}46.65 \pm 0.18 \\
\quad(79)\end{array}$ & $\begin{array}{l}78.90 \pm 0.27 \\
(69)\end{array}$ & $\begin{array}{l}5.88 \pm 0.27 \\
\quad(48)\end{array}$ & $\begin{array}{l}17.01 \pm 0.19 \\
\quad(79)\end{array}$ & $\begin{array}{l}32.44 \pm 0.16 \\
\quad(85)\end{array}$ & $\begin{array}{l}73.05 \pm 0.27 \\
\quad(91)\end{array}$ \\
\hline 400 & $\begin{array}{l}19.93 \pm 0.18 \\
\quad(71)\end{array}$ & $\begin{array}{c}39.00 \pm 0.20 \\
\quad(75) \\
\text { Endosperm }\end{array}$ & $\begin{array}{l}44.67 \pm 0.20 \\
\quad(76)\end{array}$ & $\begin{array}{l}76.23 \pm 0.39 \\
\quad(67)\end{array}$ & $\begin{array}{l}5.39 \pm 0.21 \\
\quad(44)\end{array}$ & $\begin{array}{c}15.72 \pm 0.24 \\
(73) \\
\text { Embryonic } \\
\text { axis }\end{array}$ & $\begin{array}{l}32.34 \pm 0.18 \\
\quad(84)\end{array}$ & $\begin{array}{c}71.31 \pm 0.15 \\
(89)\end{array}$ \\
\hline & Treatment & 0.136 & & & & 0.23 & & \\
\hline & Stages & 0.103 & & & & 0.17 & & \\
\hline & Interaction & 0.273 & & & & 0.46 & & \\
\hline \multicolumn{9}{|c|}{$\begin{array}{l}\mathrm{CD} \text { at } \mathrm{P}<0.05 \\
\text { Values in parenthesis denote enzyme activity as per cent of that in respective controls }\end{array}$} \\
\hline Conc. & & maltose prod & ced/endosperm & & & maltose produ & d/embryonic ax & \\
\hline of & & Days after & germination & & & Days afte & ermination & \\
\hline $\begin{array}{c}\text { lead } \\
(\mathrm{ppm})\end{array}$ & 3 & 6 & 9 & 12 & 3 & 6 & 9 & 12 \\
\hline 0 & $13.71 \pm 0.18$ & $30.51 \pm 0.24$ & $33.60 \pm 0.20$ & $76.95 \pm 0.15$ & $4.71 \pm 0.12$ & $9.18 \pm 0.18$ & $15.78 \pm 0.15$ & $42.57 \pm 0.15$ \\
\hline 25 & $\begin{array}{l}14.61 \pm 0.12 \\
\quad(106)\end{array}$ & $\begin{array}{l}28.59 \pm 0.12 \\
(94)\end{array}$ & $\begin{array}{l}34.59 \pm 0.12 \\
\quad(95)\end{array}$ & $\begin{array}{l}66.21 \pm 0.15 \\
(85)\end{array}$ & $\begin{array}{l}4.80 \pm 0.15 \\
(106)\end{array}$ & $\begin{array}{l}8.79 \pm 0.15 \\
\quad(96)\end{array}$ & $\begin{array}{l}15.00 \pm 0.24 \\
(96)\end{array}$ & $\begin{array}{l}42.63 \pm 0.12 \\
\quad(100)\end{array}$ \\
\hline 50 & $\begin{array}{c}14.40 \pm 0.21 \\
(105)\end{array}$ & $\begin{array}{c}27.12 \pm 0.18 \\
(89)\end{array}$ & $\begin{array}{c}30.09 \pm 0.18 \\
(82)\end{array}$ & $\begin{array}{c}60.48 \pm 0.18 \\
(80)\end{array}$ & $\begin{array}{c}4.44 \pm 0.12 \\
(93)\end{array}$ & $\begin{array}{c}8.43 \pm 0.18 \\
(93)\end{array}$ & $\begin{array}{c}14.76 \pm 0.12 \\
(94)\end{array}$ & $\begin{array}{c}42.30 \pm 0.18 \\
(99)\end{array}$ \\
\hline 100 & $\begin{array}{l}13.77 \pm 0.18 \\
(100)\end{array}$ & $\begin{array}{l}26.25 \pm 0.15 \\
\quad(86)\end{array}$ & $\begin{array}{l}29.01 \pm 0.12 \\
\quad(79)\end{array}$ & $\begin{array}{l}57.57 \pm 0.15 \\
\quad(74)\end{array}$ & $\begin{array}{l}1.65 \pm 0.15 \\
(36)\end{array}$ & $\begin{array}{l}7.74 \pm 0.18 \\
\quad(83)\end{array}$ & $\begin{array}{l}14.46 \pm 0.12 \\
(92)\end{array}$ & $\begin{array}{l}41.88 \pm 0.18 \\
(98)\end{array}$ \\
\hline 200 & $\begin{array}{l}13.50 \pm 0.21 \\
(98)\end{array}$ & $\begin{array}{c}24.84 \pm 0.15 \\
(81)\end{array}$ & $\begin{array}{c}27.30 \pm 0.15 \\
(75)\end{array}$ & $\begin{array}{c}54.12 \pm 0.15 \\
\quad(70)\end{array}$ & $\begin{array}{c}0.85 \pm 0.18 \\
\quad(18)\end{array}$ & $\begin{array}{c}7.20 \pm 0.18 \\
(79)\end{array}$ & $\begin{array}{c}14.22 \pm 0.12 \\
(90)\end{array}$ & $\begin{array}{c}40.95 \pm 0.15 \\
(96)\end{array}$ \\
\hline 300 & $\begin{array}{c}12.93 \pm 0.18 \\
(94)\end{array}$ & $\begin{array}{c}23.79 \pm 0.18 \\
(78)\end{array}$ & $\begin{array}{c}26.04 \pm 0.04 \\
\quad(71)\end{array}$ & $\begin{array}{c}45.51 \pm 0.15 \\
\quad(58)\end{array}$ & $\begin{array}{c}0.51 \pm 0.15 \\
\quad(11)\end{array}$ & $\begin{array}{c}6.72 \pm 0.15 \\
\quad(73)\end{array}$ & $\begin{array}{c}14.07 \pm 0.15 \\
(89)\end{array}$ & $\begin{array}{c}40.29 \pm 0.18 \\
(95)\end{array}$ \\
\hline 400 & $\begin{array}{c}12.42 \pm 0.15 \\
(91)\end{array}$ & $\begin{array}{c}22.38 \pm 0.21 \\
(73) \\
\text { Endosperm }\end{array}$ & $\begin{array}{c}24.51 \pm 0.12 \\
(66)\end{array}$ & $\begin{array}{c}43.21 \pm 0.15 \\
\quad(56)\end{array}$ & $\begin{array}{c}0.38 \pm 0.12 \\
(07)\end{array}$ & $\begin{array}{c}5.64 \pm 0.18 \\
(59) \\
\text { Embryonic } \\
\text { axis }\end{array}$ & $\begin{array}{c}13.80 \pm 0.18 \\
(87)\end{array}$ & $\begin{array}{c}39.84 \pm 0.18 \\
(93)\end{array}$ \\
\hline & Treatment & 0.150 & & & & 0.120 & & \\
\hline & Stages & 0.090 & & & & 0.090 & & \\
\hline & Interaction & 0.243 & & & & 0.271 & & \\
\hline
\end{tabular}

\section{REFERENCES}

Allinson, DW; Dziala, C (1981). The influence o lead, cadmium and nickel on the growth of rye grass and oats. Plant soil 62: 81-89.

Bansal, P; Sharma, P; Dhindsa, KS (2001). Impact of lead and cadmium on activities of hydrolytic enzymes in germinating pea seeds. Annals of Agri Bio Research 6(1): 113-122.

Bewley, JD (1997). Seed germination and dormancy. Plant cell 9: 1055-1066.

Bindu, SJ; Bera, AK (2002). Effect of $\mathrm{Cd}$ on mobilization of food reserves and partitioning of dry matter during seedling development in mungbean. Advances in Plant Science 15(2): 445-448.

Deep, V; Gupta, K; Sawhney, SK (2002). Effect of lead on starch mobilization in germinating chickpea seeds. Journal of Plant Biology 29: 85-89.

Dua, A; Sawhney, SK (1991). Effect of chromium on activities of hydrolytic enzymes in germinating pea seeds. Environ Exp Sof 31: 133-139.

Hedge, JE; Hofreiter, BT (1962). Carbohydrate chemistry. V-17. Academic Press, New York.

* Corresponding author: Gupta, $\mathrm{K}$ 
Jaja, ET; Odoemena, CSI (2004). Effect of Pb, $\mathrm{Cu}$ and $\mathrm{Fe}$ compounds on the germination and early seedling growth of tomato varieties. Journal of Applied Science and Environment Management 8 (2): 51-53.

Khan, S; Khan, NN (1983). Influence of lead and cadmium on the growth and nutrient concentration of tomato and egg plant. Plant and Soil 74: 387-394.

Marbach, I; Mayer, AM (1976). Respiration and utilization of storage material in wild and cultivated pea seeds during germination. Physiologia Plantarum 38: 126-130.

Meagher, RB (2000). Phytoremediation of toxic elemental and organic pollutants. Current Opin Plant Biol 3: 153-162.

Mishra, A; Choudhuri, MA (1997). Differential effect of $\mathrm{Pb}^{2+}$ and $\mathrm{Hg}^{2+}$ on inhibition of germination of seeds of two rice cultivars. Indian Journal of Plant Physiology 2 (1): 4144.

Mukherji, C; Mukherji, S (1990). Metabolism of germinating rice seeds as influenced by toxic concentrations of cadmium. Indian $\mathrm{J}$ Plant Physiol 33: 190-196.

Nelson, N (1944). A photometric adaptation of Somogy's method for determination of glucose. J Biol Chem 153: 375-380.
Odjagba, VJ; Fasidi, IO (2006). Effects of heavy metals on some proximate composition of Eichhornia crassipes. Journal of Applied Science and Environment Management 10 (1): 83-87.

Osuji, GO; Haby, VA; Beyene, A; Madu, WC; Mangaroo, AS (1998). The isomerization of glutamate dehydrogenase in response to lead toxicity in maize. Biologia Plantarum 40 (3): 389-398.

Raskin, I; Ensley, BD (2000). Phytoremediation of toxic metals using plants to clean up the environment. John Wiley and Sons, New York.

Roy, SB; Bera, AK (2002). Effect of mercury and manganese on amylase, protease and peroxidase in germinating seeds of mungbean. Advances in Plant Science 15(2): 98-103.

Swain, RR; Dekker, EE (1966b). Seed germination studies II: Pathways for starch degradation in germinating pea seedlings. Biochem Biophys Acta 122: 87-100.

Thimmaiah, SK (1989). Changes in amylase activity of wheat during germination. Indian $\mathrm{J}$ Plant Physiol 32: 258-260.

Whitton, BA (1970). Toxicity of heavy metals to fresh water algae. A review. Phykos 9: 166125 .

Yomo, H; Varner, JE (1973). Control of formation of amylases and proteases in the cotyledons of germinating peas. Plant Physiology 51: 708713. 